\title{
Acquisition, Learning, or Development of Language? Skinner's "Verbal Behavior" Revisited
}

\author{
Susana López Ornat and Pilar Gallo \\ Complutense University of Madrid
}

\begin{abstract}
In 1957, Skinner, in his "Verbal Behavior", proposed an explanation on how a language is learned. In 1959, Chomsky strongly argued the non-learnability of language, establishing in the field of developmental psycholinguistics the substitution of the term "learning" for that of "acquisition". Currently, the constructivist models describe language acquisition as a process of ontogenetic, gradual, complex, and adaptive change. This new theoretical framework has been especially useful for rereading Verbal Behavior because it facilitates recovering the Skinnerian learning mechanisms. This can be observed in the recent research trends that recapture reinforcement and imitation (echoic responses), although they are now located in the initial phases of the process and are included in a cognitive dynamic that, by gradually increasing its complexity, can achieve grammar. The new constructivist theoretical framework, by retrieving the functional and referential aspects of language, can also take advantage of the classic Skinnerian proposal about the pragmatic types of verbal behavior, providing it with new meaning.
\end{abstract}

Keywords: Language Learnability, Imitation, Reinforcement, Skinner

En 1957 Skinner, en su obra Conducta Verbal, propuso una explicación sobre cómo se aprende un lenguaje. En 1959 Chomsky argumentó contundentemente la no aprendibilidad del lenguaje instaurando en el ámbito de la psicolingüística evolutiva la sustitución del término aprendizaje por el de adquisición. En la actualidad los modelos constructivistas describen la adquisición del lenguaje como un proceso de cambio ontogenético, gradual, complejo y adaptativo. Este nuevo marco teórico ha resultado especialmente idóneo para la re-lectura de la Conducta Verbal porque permite cierta recuperación de los mecanismos de aprendizaje skinnerianos. Esto se manifiesta en las recientes líneas de investigación que recuperan el refuerzo y la imitación (respuestas ecoicas) aunque localizándolos en las fases iniciales del proceso e incluyéndolos en una dinámica cognitiva que, al aumentar gradualmente su complejidad, puede llegar a obtener una gramática. Además, el nuevo marco teórico constructivista, al recuperar las vertientes funcionales y referenciales del lenguaje, puede aprovechar la clásica propuesta skinneriana sobre los tipos pragmáticos de conducta verbal, dotándola de un nuevo sentido.

Palabras clave: Aprendibilidad del Lenguaje, Imitación, Reforzamiento, Skinner

Correspondence concerning this article should be addressed to Susana López Ornat, Departamento de Psicología Básica II, Facultad de Psicología. Universidad Complutense de Madrid. Campus de Somosaguas. 28223 Madrid (Spain). E-mail: slornat@psi.ucm.es

Translation: Virginia Navascués Howard. 
The cognitive system is capable of developing a language by means of a process of change whose most significant milestones are found in the first years of life. The Skinnerian proposal about how this system interacts with the linguistic and extralinguistic experience to learn a language appears in Skinner's (1957) Verbal Behavior. Due to the fact that it focused exclusively on this experience (as dispenser of the behavior to be imitated and of the appropriate reinforcement program for shaping behavior), it was literally flattened by Chomsky's (1959) critique. The Chomskian model (innatist-not developmental-formalist) proposes to explain the acquisition of language, reducing to the bare minimum the role of experience. Sixty years after the development of cognitive psychology, the knowledge accumulated about the mind's functioning is stimulating psycholinguists to relocate the topic in question to a more psychological area. This relocation can be specified in the following question: Why does a child acquire, and not learn, a language?

The term acquisition is in consonance with the Chomskian model. In this work, we propose to analyze what this model is based on and how the current theoretical perspectives (grouped under the general name of "constructivism") offer a rigorous alternative, and can also integrate some aspects noted in Skinner's Verbal Behavior in a new framework.

In the first place, constructivism conceives the development of language as a process of change that takes place during ontogenesis. This proposal differs from the Chomskian representational-grammatical innatism, although it does not discard other types of innatism (structural or chronotopic). This constructivist notion can recover the fact that Skinner's arguments never exceed the framework of the child's interaction with the environment. As we now know, this framework is prior to birth.

In the second place, constructivism conceives the development of language as a global process. The complexities of language are not resolved, but are instead gradually built. The basic Skinnerian mechanisms of learning, reinforcement and imitation, are being retrieved as necessary to account for the initial phases of this development. But constructivism exceeds the Skinnerian model many times over because the latter does not explain the emergence of grammatical complexity.

In the third place, constructivism conceives the development of language as a process of adaptive change. Skinnerian verbal behavior proposes contingency relations (referential in the tacts, pragmatic in the mands) with experience. This viewpoint can be recovered in the new theoretical framework because, contrary to the Chomskian model, it contemplates the development of grammatical knowledge-absent in Skinner-as a huge adaptive success of the process of linguistic development.

The use of the term language "acquisition" is generalized in the field of psycholinguistics and refers to the process of cognitive change, of vital importance to children, which takes place in the first years of life and culminates in the mastery of the grammar of their language. But why does a child "acquire" and not "learn" a language? In order to answer this question, we must go back to Skinner's work (Verbal Behavior, 1957) and the critique of this work by Chomsky (Review of B. F. Skinner's Verbal Behavior, 1959). Skinner was interested in the behavioral aspect of language. Chomsky was interested in the origin of the grammatical knowledge that organizes it.

Thus, in Verbal Behavior, Skinner described language as a behavior that, as such, is learned: "A child learns verbal behavior when utterances relatively lacking in pattern, and which are selectively reinforced, gradually take on forms that produce the appropriate consequences in a given verbal community" (Skinner, 1957, p. 40).

Chomsky's criticism of this work led research to focus on the origin of the grammatical knowledge that a child begins to exhibit from the age of 30 months. But, for this purpose, Chomsky assumed that language is unlearnable. He argued (Chomsky, 1959, 1995), that language was not learnable because:

1. Language is a surprisingly early acquisition that, nevertheless, involves building a complex formal system (grammar). And this is performed by a cognitive system that is still prelogical and preoperative.

2. Language is acquired with no apparent effort.

3. Language is acquired without any explicit instruction, that is, nobody teaches the child to talk.

4. Language is acquired despite "stimulus poverty." Grammatical information is not found explicitly in the stimulus input and, in addition, this input contains informative noise, interruptions, differences between speakers, and is grammatically incomplete.

Chomsky's critique has come to be considered as one of the essential factors in the transition towards cognitive psychology. Its specific influence in developmental psycholinguistics is still evident nowadays, 60 years later, in the generalized adoption of the term "acquisition." This term contains three implicit criticisms of Skinner:

1. Linguistic knowledge can be "learned" because it is predetermined by genetic grammatical knowledge: The acquisition process is guided by the principles of Universal Grammar, transmitted genetically.

2. In any case, linguistic knowledge is the result of a very complex learning process, which Skinner's model does not explain, or explains very scarcely.

3. Grammatical knowledge is the result of specialized learning mechanisms, different from general cognitive mechanisms, and determined genetically in a specific way. Language acquisition mechanisms are not general at any point in the process.

Thus, the term "acquisition" began with Chomskian, linguistic roots, and it emphasized the notion that grammar is triggered by the environment rather than learned. Also, grammatical development would be independent of other kinds of developments, linguistic or otherwise: semantic, pragmatic, cognitive. 
But this term was maintained in alternative models ("constructivism") to Chomsky's model, as evidence grew revealing that the grammar of a language is learned, but in a very complex way. Evidence showed that it was not sufficient to "land" in a linguistic setting (according to Skinner, a setting that provides the input to be learned and that reinforces progressive approximations to the input) but instead, it was necessary to add internal cognitive dynamics of which no trace is found in behavioral theories.

Currently, recent advances in psycholinguistics and developmental neuroscience (López Ornat, 2003b) allow us to conceive that language is "learned" from a genetic inheritance that is not specifically grammatical, by means of an extremely complex process of self-organized and timetaking change (until adolescence).

The goal of this work is to review Skinner's contributions in the current context, with the aim of rescuing them as basic mechanisms contributing to early language learning. As general mechanisms of cognitive change, which may help explain the first-pregrammatical-steps of the acquisition process, without forgetting that the following steps require much more complex theories, capable of accounting for the deep representational changes involved in language acquisition. These more complex theories are currently grouped under labels such as "constructivism," "cognitive-developmental neuroscience," and "emergentism" (Beer, 2000; López Ornat, 1991, 1994, 1996, 1997, 1999, 2001, 2003a, 2003b; Quartz \& Sejnowski, 1997). They all respond to the Chomskian challenge to explain the emergence of grammar, but they respond from the assumption of the learnability of grammar during ontogenesis. The most interesting aspect for us now is that, through learnability, we can recover the basic Skinnerian mechanisms of reinforcement and imitation and claim their intervention at the starting point of linguistic development. The novelty is that this learnability, in contrast to Skinnerian learnability, assumes the complexity that this system gradually achieves when it is grammatically formalized.

Another Skinnerian viewpoint that can be recovered by constructivism is the functional approach (Tomasello, 2003) as such: During language development, a formalization process occurs which is performed by a living system that has to adapt and that, by becoming grammatical, is better adapted. The development of grammar is a huge adaptive success.

We will now specify our proposal about some Skinner contributions that are relevant for current theories. We shall do this within the three learnability assumptions: The development of language is a process of change that is: (a) ontogenetic, (b) gradual and complex, and (c) adaptive.

\section{Language Development as an Ontogenetic Change Process}

A functional analysis of the verbal community is not part of this book, but a few standard problems call for comment.
One of them is the old question of the origin of language. Early man was probably not very different from his modern descendants with respect to behavioral processes. If brought in to a current verbal community, he would probably develop elaborate verbal behavior. What was lacking was not any special capacity for speech but certain environmental circumstances (Skinner, 1957, p. 461).

As mentioned, the arguments in favor of the genetic origin of grammar have greatly influenced developmental psycholinguistics. Despite various modifications of these theories, from this perspective, no convincing explanations have been generated to explain issues such as interlingual differences or irregularities. Representational innatism has not been very convincing and it lacks a physiological base. In turn, constructivism accepts architectural innatismneuron types, cortical layers..., and chronotopy: timing of linguistic maturation (Elman 1993; Elman et al., 1996). It is currently known that, at birth, children have already begun to learn to process linguistic information, limited to prosodic information, which is audible in the uterus during the last three months of pregnancy (Jusczyk, 1997; Lecanuet \& Granier-Deferre, 1993), and that they gradually learn to give meaning to the entire linguistic input.

A recoverable aspect of Verbal Behavior is that it places explanations, with no hesitancy, in the postnatal period, so that development becomes dependent on experience (Santacruz, 1987). Readers are reminded that in Skinner's and Chomsky's times, until 1995, no one knew that this experience could begin during the $7^{\text {th }}$ month of gestation.

We believe that it is interesting to recover the function of experience because it guides research towards the discovery of the relations between experience and cognitive change (Tomasello, 2000). Nowadays, this is the nucleus of the problem and issues of genetic inheritance are in the periphery. Whatever the genetic inheritance may be, at birth, grammar, language, and verbal behavior are not yet present. How are the first steps taken towards these processes? And how can Skinner's theory contribute to our comprehension of them? These are the questions we focus on in the following sections.

\section{The Development of Language as a Process of Gradual and Complex Change}

The parent sets up a repertoire of responses by reinforcing many instances of a response. Obviously, a response must appear at least once before it is strengthened by reinforcement. It does not follow, however, that all the complex forms of adult behavior are in the child's unconditioned vocal repertoire. The parent need not wait for the emergence of the final form. Responses of great intricacy can be constructed in the behavior of an organism through a procedure illustrated [...] (Skinner, 1957, p. 29). 
In teaching the young child to talk, the formal specifications upon which reinforcement is contingent are at first greatly relaxed. Any response which vaguely resembles the standard behavior of the community is reinforced. When these begin to appear frequently, a closer approximation is insisted upon. In this manner, very complex verbal forms may be reached. (Skinner, 1957, pp. 29-30).

The above fragments of Verbal Behavior show how Skinner accounted for the learning of language. In this explanation, we can emphasize two facets:

1. The gradual conception of language: parents reinforce the successive approximations to the adult linguistic model. Skinner thereby proposed that the first productions are far from the model and that, in successive steps, they come closer and closer. He also indicated the essential need for a model. Both issues are current and coherent with the constructivist viewpoint.

2. However, the Skinnerian conception of this learning is linear: "his" learning system is not a system that changes as a result of its activity (Mateo, 2000). Skinner's learning mechanisms cannot change and, therefore, cannot ever induce grammar.

For years, in the field of language acquisition, theories of Chomskian influence (Chomsky, 1959, 1995) proposed that linguistic knowledge develops as a result of the triggering action of the environment and is acquired without errors when the speaker's linguistic competence is activated. Contrariwise, from the constructivist viewpoint, the languageacquisition-system is a complex adaptive system (Bedau, 2003) that is gradually transformed (López Ornat, 1994). Hence, the gradualness of development is valid again today.

Specifically, we suggest that, in order to understand the beginning stages of linguistic development—pregrammatical ones-which are strongly but not exclusively dependent on experience, Skinner-rooted notions are once more taken into account. In fact, we will comment upon some current research trends that reflect and redescribe two of these notions: reinforcement and "imitation."

\section{What does gradual mean?}

The kinds of behavior in which we are usually interested have, as we have seen, an effect upon the environment which has a return effect upon the organism. Such behavior may be distinguished from activities which are primarily concerned with the internal economy of the organism by calling activities which operate upon the environment "operant behavior." Any unit of such behavior is conveniently called "an operant." For most purposes, "operant" is interchangeable with the traditional "response," but the terms permit us to make the distinction between an instance of behavior ('So-and-so smoked a cigarette between 2:00 and 2:10 yesterday') and a kind of behavior (cigarette smoking). The term "response" is often used for both of these, although it does not carry the second meaning easily. The description of an instance of behavior does not require a description of related variables or of a functional relation. The term operant, on the other hand, is concerned with the prediction and control of a kind of behavior. Although we observe only instances, we are concerned with laws which specify kinds (Skinner, 1957, p. 20).

Skinner distinguished two response levels: the unit, which is a simple response, and the operant response, which is a response category. This distinction can be related to the current differentiation between tokens and types (Plunkett, 1993, 1995). According to the notion of local learning (Lieven, Behrens, Spears, \& Tomasello, 2003), both natural and artificial neural networks learn to respond to types from their experience with tokens. This develops into a learning language process that, at first, advances practically item-byitem. A certain language structure (an inflection, an agreement, a syntactic structure) will only be used correctly with/for one or a few words, and not with others. Also, a linguistic production (word or phrase) will only be used correctly at first in/for specific local contexts, and not in generalized ones. In the transition from tokens to types, it is interesting to detect when an utterance switches from being an unanalyzed block to a being framework with interchangeable parts (Lieven, Pine, \& Baldwin, 1997; Pine \& Lieven, 1997; Smith, Nix, Davey, López-Ornat, \& Messer, 2003). For example, at 18 months, a little girl learned the utterance I want cookies to subsequently extend it to different objects: I want crayons, I want Papa, and I want Michael.

However, the gradual increase in complexity does not only affect production or linguistic output. Other recent research trends point out that, throughout the entire development of language, both the input and the learning system become more complex. The system filters the quantity and quality of input it receives as a function of its developmental state (Elman, 1993; López Ornat, 1994) and, in addition, it modifies itself, creating various transition stages (López Ornat, 1996, 1997, 2001, 2003a; Mariscal, 1997, 2001). Thus, children's intermediate grammars have the following characteristics:

1. Concrete: They are made up of rules that do not have the generalization level of adult rules. For example, the subject we studied longitudinally, María, began to produce first-person inflections with action verbs only (Gallo, 1994a).

2. Incorrect: When children's speech undergoes a frequent longitudinal follow-up, grammatical errors are observed. For example, María, when trying to incorporate pronouns in sentences, spent some time producing errors such as: yo no a camita [me not to bed] (verb omission), yo sabe [me knows] (agreement), yo a sentá [I to to sit] (impersonal verb) (Gallo, 1994a).

3. Inconsistent: Within the same observational session, there are correct and incorrect versions of the same linguistic structure. For example: oto utara, ota utara [another + masculine spoon, another + feminine spoon] (inconsistency in gender agreement: López Ornat, 1996; 2003; Mariscal, 1997; 2001). 
Current constructivist models propose a system that starts applying general cognitive processing mechanisms to the linguistic input until it is able to extract some partial grammatical regularity. As children advance in the statistical definition of partial regularities (Hauser, Chomsky, \& Fitch, 2002; López Ornat, 1994), the acquired grammatical knowledge, which is partial and simple, permits them to obtain new grammatical knowledge in a way that is-comparatively-independent of experience and more dependent on internal abstraction work (Marcus, 1999; McClelland \& Plaut, 1999). From this viewpoint, one could refer to a "learning" process in the first-pregrammatical-phases of linguistic development and, in advanced phases, to "grammatical acquisition."

\section{General Learning Mechanisms}

\section{Reinforcement}

For Skinner, parents were very important as reinforcing agents and, therefore, molders of the child's verbal behavior. It was subsequently shown that there are no explicit corrections of grammatical errors (Brown \& Hanlon, 1970), that is, parents do not inform their children about whether or not an utterance is grammatical. This was confirmed in the authors' longitudinal study (López Ornat, Gallo, Fernández, \& Mariscal, 1994) during which we observed some corrections of articulatory or semantic errors, but only one grammatical correction:

Articulatory correction: Age: 2.00

María: No se gompe, no se gompe, ¿sabes? [It doesn't bake, it doesn't bake, you know?]

Father: Gompe no, rompe. [Not bake, break.]

María: Se me gompe. [It bakes.]

Father: Rompe. [Breaks.]

María: Guompe. [Bwakes.]

Father: Rompe. [Breaks.]

María: Gompe. No se me guompe, no se me guompe. [(Bakes. It doesn't bwake, it doesn't bwake.]

Father: No. Si le pegas golpes sí que se rompe. [No. If you hit it, it breaks.]

Semantic corrections: Age: 1.09

Mother: Chuta. [Kick.]

María: Chuta (throws the ball).

Mother: Chuta, chutar es con el pié, María, botar es con la mano. [Kick, kick is with your foot, María, throw is with your hand.]

María: E pié. [E foot.]

Mother: Chutar es con el pie. [Kick is with your foot.] Age: 1.10

María: A mancas a soubá [sleeves to poul up] (lowering the sleeves of her sweater).

Mother: No, eso es bajarlas. [No, that's lowering them.]
The only grammatical correction: Age: 2.03

Mother: ¿A qué le vas a invitar? [What are you going to invite him to?]

Girl: Mira, a tomar una caña, parese. [Look, to a beer, think.]

Mother: Me parece. [I think.]

These examples are complemented with what we could call "deafness-of parents-to errors":

Age: 2.01

María: Si sabo cocinar. [I know cook.]

Father: ¿Ah sí?, ¿qué sabes hacer? [Oh, yes? What do you know how to cook?]

Age: 2.01

María: Voy a cojo una silla. ¿Eta? Eta [I go gets chair. This one? This one.]

Father: Oye, iqué triciclo más bonito! [Hey, what a pretty tricycle!]

Although it is obvious that Skinner exaggerated the parents' role, nonetheless, they cannot be discarded as participants in the linguistic development of their children. In the longitudinal study, there are three interesting parent's behaviors that could make up an implicit teaching program:

1. Going down to the child's level: The parents were "imitating" their daughter's proto-language:

Age: 1.08

Mother: Oye, ¿mamá qué tiene en vez de botas? [Hey, what does mommy have instead of boots?]

Girl: Botas. [Boots.]

Mother: Los zapatos. Díselo a papá qué son éstos. [The shoes. Tell Papa what these are.]

Girl: El nene....apatos. [The baby....'oes.]

Mother: Apatos. ['Oes.]

Girl: E nene a botas. [The baby a' boots.]

Mother: Nene a botas, ¿y mamá? [Baby a' boots. And mommy?]

Girl: Nene a botas. [The baby a' boots.]

Mother: No, nene botas, ¿y mamá?[No, baby boots; and mommy?]

Girl: Mamá apatos. [Mommy 'oes.]

Mother: ¿Y papá? [And Papa?]

Girl: Papá apatos. [Papa 'oes.]

Mother: Papá apatos, ¿y el nene? [Daddy 'oes; and the baby?]

Girl: ¡Bota! As botas. [Boots! A' boots.]

Mother: Las botas (laughing). [The boots.]

Age: 1.07

María: ;Oh e tete!

Mother: ¡Tete tene la nena! Espera, vamos a quitarle los pantalones. [Oh, the girl has "tete”. Wait, let's take off her pants.]

María: Nena. [Girl.]

2. Reinforcing very primitive utterances:

Age: 1.07

Mother: ¿Sabes dónde vamos a ir? [Do you know where we're going?] 
María: A calle. [Utdoors.]

Mother: A la calle ¿con quién? [Outdoors- with whom?]

María: Apá a calle. [Ad utdoors.]

Mother: Con papá a la calle ¿y con quién más?[With dad outdoors and who else?]

María: Apá a calle. [Ad utdoors.]

Mother: Muy bien, ¿y con quién vas a la calle? [Very Age: 1.07 well, and with whom are you going outdoors?]

Mother: ¿Qué tenías en las manos? [What did you have in your hands?]

María: A má caca. [A 'and dirty.]

Mother: Claro, pero cuando estabas malita tenías pupa ¿no? [Sure, but when you were sick, it hurt, no?]

3. Developing along with the child:

Age: 1.07

María: A pá. [Ap.]

Mother: ¿A pá? [Ap’?]

María: $M n$.

Mother: Venga, aupa. [Come on, up.]

Age: 2.07

María: Es que quiero ahí porque ahí no me molesta. [I want there because there it doesn't bother me.]

Mother: Pero es que si te pones ahí no la ve papá. [But if you sit there, papa doesn't see it.]

This implicit program seems to have the global aim of promoting the child's participation in the communicative exchange. This participation is important because this is how the child receives the language model. Bohannon and Stanowick (1988) pointed out two interesting ways of providing this model-syntactic expansions and semantic extensions-that could even be more informative than the simple grammatical corrections because they offer the correct linguistic model. We will describe them below, with examples in Spanish taken from our longitudinal study.

Expansions: The parents complete the child's utterances

Age: 1.07:

María: Máa. (She looks at her hand.)

Father: ¿Eh?

María: Caca e má. [Ha' dirty.]

Father: ¿Tienes caca en la mano? [Is your hand dirty?] Age: 1.09:

Mother: ¿Qué ha pasado? [What has happened?]

María: Acá. [Fell.]

Mother: ¿Te has caído? [Did you fall?]

María: Sí. [Yes.]

Mother: ;Mecachis! [Goodness!]

Semantic extensions: The parents continue the topic initiated by the child.

Age: 1.07:

María: Aquí e nene. [Here a' baby.]

Mother: Aquí el nene está muy bien. ¿A qué sí?. Un poquito de jabón para mi nene. ¡Uy jabón!. Dame las manitas. [The baby is fine here, right? A little soap for my baby. Oh, soap! Give me your hands.]
Age: 1.09:

María: Chupa a meia a guau-guau. [Bow-wow lick stocking]

Mother: ¿Te ha chupado la media el guau-guau?. ¡Mecachis!. Le vamos a hacer tas-tas [Did the bow-wow lick your stocking? Goodness! We are going to spank him.]

Age: 1.09:

Father: ¡Qué ojos tienes, hija! [What lovely eyes you have, daughter!]

Girl: Caca o pes. [Dirt a' feet.]

Father: Ya, y además de caca en los pies, tienes unos ojos muy bonitos. [Yes, and besides dirty feet, your eyes are very pretty.]

A systematic reinforcing program by parents has not been observed, but instead generalized reinforcement of the child's participation in conversations. Nevertheless, there is no doubt that their contribution as providers of linguistic material on which the child's cognitive system works, is essential. The studies of this material began with the description of motherese, or special speech that adults direct to children, characterized by its simplification, exaggerated tone, and the use of basic vocabulary and simple sentences. Analysis has shown that it is a clear, simple, and well formed speech that could facilitate learning (Snow \& Ferguson, 1977). In order to study in detail the relation between motherese and learning, investigations such as that of Pine in 1994 analyze both the children's output and their parents' speech with the aim of determining which part of the adult input the children work on and how they do it.

\section{Imitation}

In the simplest case in which the verbal behavior is under the control of verbal stimuli, the response generates a sound pattern similar to that of the stimuli: for example, when listening to the sound bearded, the speaker says bearded (Skinner, 1957, p. 55).

Skinner, throughout the text of Verbal Behavior, does not talk about imitation, but rather "echoic" verbal behavior. Despite this fact, we will use the word "imitation," as it refers to the same concept.

Skinner treats imitation rather superficially, and his most interesting contribution on this topic is to have popularized this notion, to have guided investigation towards it. Both the first cognitivism (Bruner, 1975) and generativism (Chomsky, 1959) found it easy to criticize the Skinnerian idea of imitation as a mechanism of language acquisition, because this process clearly surpasses the limits imposed by imitation. Therefore, the topic was loaded with negative theoretical connotations: mechanicism, reductionism. Even so, research was not abandoned and currently, imitation is a vital topic both in neurocognition-developmental or otherwise - and in cognitive science (Decety \& Sommerville, 2003). 
Sticking to imitation in the process of language acquisition, we shall see how the current notion of imitation has changed, it has been reutilized, and has become much more precise.

In the first place, nowadays no one denies that-among other things — children begin to learn language by imitating linguistic examples. The issue is that, in the end, what they learn is the language (the formal conventional system) and not just speech samples. Therefore, imitation plays an essential role in the start of the process and, at the same time, it cannot explain the first grammatical successes, which are partial but combinatory. The following quotation suggests that Skinner guessed at this limitation:

The first echoic operants acquired by a child tend to be fairly large integral patterns, and they are of little help in permitting him to echo novel patterns echoically. A unit repertoire at the level of separable "speech sounds" develops later and often quite slowly. Small echoic responses may be reinforced by parents and others for the express purpose of building such a repertoire. The child is taught to repeat small sound patters such as ä, sp, and so on. Such a basic echoic repertoire may be acquired at the same time as other forms of verbal behavior or even larger echoic units. The child may emit responses as large as syllables, words, or even sentences as unitary echoic operants. For help in echoing a novel stimulus, however, he falls back upon the single-sound repertoire (Skinner, 1957, p. 62).

The limitation of the Skinnerian treatment of the topic does not make it less interesting. We mentioned that the modern constructivist viewpoints have reused and modified the notion of imitation and its developmental function. Let us see how:

1. Imitation is taken to indicate that the acquisition process of a linguistic structure has started, that is, an initial step, before comprehension and production of the said structure (Fraser, Bellugi, \& Brown, 1963; López Ornat, 1994). The imitated exemplars can be represented and stored and, therefore, internally analyzed, in search for statistical regularities (López Ornat, 1994, 1999; McClelland \& Plaut, 1999; Seidenberg, 1997). In addition, the imitated exemplars must have been perceived, that is, identified within the signal and segmented from it. But the system must also have oriented to these exemplars and selected them.

2. The "predecessor" nature of linguistic imitation seems to be reproduced on the phylogenetic scale: among the hominids, vocal mimicry precedes the emergence of complex articulate language by about two million years (MacWhinney, 2002). Therefore, it seems that the capacity to imitate others' behaviors using fine-tuned sensorimotor coordination, voice, rhythm, and melody, even without understanding/ knowing/ sharing the other's communicative intention (vocal or gestural mimicry), was an evolutionary step prior to the use of complex structured language, such as ours, which would be fairly recent.

3. However, imitation as such is currently considered to develop: for example, in linguistic development, Pérez-Pereira and Castro (1994) distinguish between different types of imitation, which would have different developmental values depending on whether the model is repeated exactly, or it is repeated and extended, or it is repeated and reduced. They also distinguish and compare, for a specific developmental moment in the child, the proportion of productive utterances to routine utterances (Pérez-Pereira, 1994), repetitions, and imitations.

4. Complementarily, in compared cognition (Call \& Carpenter, 2003; Tomasello, 2003), various components of imitation are analyzed separately: action, goal, and result. Three types of imitation are differentiated as a function of this: imitation per se (when the subject reproduces the action, the goal, and the result), mimicry (focused on the action), and emulation (focused on the result). In their research with children and chimpanzees, they attempted to arrange these components evolutionarily. Let us see an example of imitation produced by an 18-month old girl:

Action (linguistic utterance): ¿Quieres? ¿Quieres? [Do you want? Do you want?] (Pregrammatical utterance: the child did not yet produce any person discrimination in the verbal inflection).

Goal (final aim): to get a cookie (She looks at the cupboard, at the adult, and points to the place where the cookies are kept. When the adult gives her the cookie, she stops saying it.)

Result (effect): She gets a cookie

5. There is another "constructivist" distinction portrayed in this example: the time interval between the perception of the model and the child's utterance. This is relevant because it allows us to distinguish deferred imitation (in the example) as more advanced developmentally (Piaget, 1981) than immediate imitation.

6. There is current evidence of what could be part of a neurological support of imitation: the Mirror Neuron System (MNS), first described in adult maccacos. This is a series of neurons that fire not only when the subject performs an action but also when it observes another performing that action. It is tempting to relate this system to a support system of social mimicry, of imitation (Decety \& Sommerville, 2003), of Skinner's echolalia. Let us see some intuition of this notion in a fragment of Verbal Behavior:

In the standard "word association" experiment, a stimulus word is presented and the subject is asked to report the first he finds himself saying in response to it. It is necessary to instruct the subject not to repeat the stimulus word; even then, a fragmentary echoic behavior appears in so-called "clang associations"-responses which are alliterative or, rhyming, or otherwise similar to the stimulus word. A fragmentary self-echoic behavior may be shown in reduplicative forms like helter-skelter, razzle-dazzle, and willy-nilly. Pathological echoic behavior is seen in "echolalia," in which a bit of speech heard by the patient is repeated possibly many times. Echoic behavior is most commonly observed in combination with other types of control. In a conversation, for example, a slightly atypical response is often picked up and passed from speaker to speaker. The two 
halves of a dialogue will generally have more words in common than two monologues on the same subject. If one speaker says "incredible" instead of "unbelievable," the other speaker will, in general, and because of the present relation, say "incredible."

A fragmentary echoic behavior is evident when one speaker adopts the accent or mannerisms of another in the course of a conversation. If one member of a group whispers, perhaps only because of laryngitis, other members tend to do so (Skinner, 1957, pp. 35-36).

The existence of a mirror neuron system poses unsolved issues, such as establishing whether the MNS develops phylogenetically or ontogenetically, whether or not it is innate, whether the maccacos' MNS can be compared to that of humans, whether mimic activity is voluntary or involuntary, and so on.

Considering the series or rereadings of the notions of reinforcement and imitation as a whole, we see that a "cognitive wash" has added complexity to these notions, including their gradual changes over the acquisition process.

\section{Development of Language as a Process of Adaptive Change}

Linguistics has recorded and analyzed speech sounds and semantic and syntactical practices, but comparisons of different languages and the tracing of historical changes have taken precedence over the study of the individual speaker. Logic, mathematics, and scientific methodology have recognized the limitations which linguistic practices impose on human thoughts, but have usually remained content with a formal analysis, in any case, they have not developed the techniques necessary for a causal analysis of the behavior of man thinking (Skinner, 1957, p. 4).

Tomasello (2003), in his book, A Usage-Based Theory of Language, proposes that the development of language should be conceived as a series of cognitive processes working on the linguistic input. These processes would be of general domain, that is, they would categorize both linguistic experience and physical and social experience. Thus, the referential and functional roles of language would leave their current "peripheric" position in the theories of language acquisition, and would become first-order explanatory factors. Hence, for Tomasello, semantics and pragmatics should be incorporated at all levels of description, both lexical and morphosyntactic, and at all developmental levels.

But how can one integrate the computational aspects of language (phonology, morphosyntax) with the conceptual ones (semantics, pragmatic, vocabulary) in a theory of linguistic development?

In the seventies, Bruner (1975) initiated a research trend along these lines: From birth, the child is included in communicative acts with the adult. In environments of high functional value (feeding, bathing, playing, etc.), the adult establishes protoconversations with the baby. These formats or routines contribute to language acquisition by directing the child's attention towards language.

Thus, words, like perceptual figures, stand out on a stable, constant, and routine background: the format. In addition, formats are the vehicle of the functionality of language or its adaptive value, taken as the number of problems that its use solves or as the number of problems that cannot be solved because of its lack or deterioration (López Ornat, 1994). For example, Halliday (1973) differentiated among three basic pragmatic functions of infant language: instrumental ( I want), regulatory (do what I say), and interactive (you and me).

With regard to meaning, semantic bootstrapping or facilitation (Maratsos, 1998; Pinker, 1987), proposes that a series of semantic outlines guide the first grammatical acquisitions. That is, whatever their language, children start talking about the same things. They use their first linguistic expressions to refer to or to code common semantic notions. These are about things existing (attribution, possession, localization) and things happening (actor, action, patient). In an example of infant speech such as Nene agua pumba ([Baby water, splash] I fell into the swimming pool), the utterance is based on previous semantic notions: agent, localization, action.

However, these attempts to explain grammatical acquisition from pragmatic-semantic learning have never had the force claimed by Tomasello (2003) because they do not solve the problem of continuity between these acquisitions and complex grammatical acquisition.

As we shall see in the following phrases, Skinner (Cohen, 1977) did not contemplate any qualitative leap between both types of knowledge (pragmatic and grammatical). Thus, he established a distinction between behavior molded by contingencies and behavior occurring when people follow rules extracted from these contingencies. According to Skinner, rational behavior would imply providing reasons, which are sentences about the contingencies. One can manipulate rational behavior very well, as it is very similar to behavior molded by contingencies, but with a difference. Skinner also stated that people learn to extract rules and justify why they follow them (Cohen, 1977).

Thus, it seems that, for Skinner, the process of grammaticalization would be described as a process of cognitive organization to maximize the positive consequences of the child's action on the environment. Verbal behaviors are classified as a function of this behavioral goal instead of as a function of linguistic criteria. We shall see the two most representative classifications:

MANDs, which refer to the pragmatics of language: "In a given verbal community, certain responses are characteristically followed by certain consequences. 'Wait!' is followed by someone's waiting and 'Sh-h!' by silence" (Skinner, 1957, p. 35).

TACTs, which refer to the semantics of language: "The term carries a mnemonic suggestion of behavior which "makes contact" with the physical world" (Skinner, 1957, p. 81). 
Both Skinner's model and the constructivist model include semantic and pragmatic variables in the center of linguistic development. For both models, the development of grammar should be contextualized. Table 1 displays an example of the development of the imperative formulas (Gallo, 1994b), comparing the two types of knowledge: semantic and grammatical.

The constructivist model, which has slowly become an alternative to the Chomskian model, is in accordance with the Skinnerian conception, much revised and extended, of linguistic learning as a process of ontogenetic, gradual, and adaptive change. The functionality that penetrates the entire Skinnerian model is again claimed after many years during which the predominant focus of interest was excessively formal. According to Rivière (1991), the notion of a system that incorporates logical principles into its neural networks calls for concordance with the properties of the central nervous system. From this perspective, two properties stand out: adaptability, synonym of flexibility and ontogenetic change, and intentionality, synonym of meaningful activity.

In addition to the above-mentioned contributions, the importance of Skinner's work consists of its having turned-definitively-human behavior into an object of study, unshackling it from the spirit. Its merit is not to have been a pioneer in this attitude, but to have divulged it, turning scientific inspection of human activity into something natural. And he did this with wit. In 1934, Whitehead challenged Skinner to functionally explain the following linguistic utterance: No black scorpion has fallen on this table. He accompanied this utterance with the following comment: "Science can explain any human behavior except for verbal behavior." Skinner replied that to ask such a thing of behaviorism was "unfair" (Skinner, 1957, p. 457) and wrote that the very next morning, he began to write Verbal Behavior.

Table 1

Development of the Imperative Formulas. Comparison of Semantic and Grammatical Knowledge. (Gallo 1994b)

\begin{tabular}{cccc}
\hline Age & Semantic Knowledge & Morphosyntactic Knowledge & Example \\
\hline 1.09 & Action & Imperative & Sienta $[$ sit $]$ \\
1.10 & Action + Person & Clitics & Pome $[$ Put on me $]$ \\
& & $2^{\text {nd Person }}$ & Sientas $[$ You sit $]$ \\
2.01 & Negation & Subjunctive & No te vayas $[$ Don't go $]$ \\
2.04 & Consequence & Subordinate & No jubas, la tiro la tapa \\
& & & {$[$ Don't come up or I throw away the top $]$} \\
\hline
\end{tabular}

\section{References}

Bedau, M. A. (2003). Artificial life: Organization, adaptation and complexity from the bottom up. Trends in Cognitive Sciences, 7, 505-512.

Beer, R.D. (2000). Dynamical approaches to cognitive science. Trends in Cognitive Sciences, 4, 91-99.

Bohannon, J., \& Stanowick, L. (1988). The issue of negative evidence: Adults' responses to children's language errors. Developmental Psychology, 24, 694-689.

Brown, R., \& Hanlon, C. (1970). Derivational complexity and order of acquisition in child speech. In J.R. Hayes (Ed.), Cognition and the development of language (pp. 11-53). NY: Wiley.

Bruner, J. (1975). From communication to language: A psychological perspective. Cognition, 3, 255-287.

Call, J., \& Carpenter, M. (2003). On imitation in apes and children. Infancia y Aprendizaje, 26, 3325-341.

Chomsky, N. (1959). Review of B. F. Skinner's Verbal Behavior. Language 35, 1, 26-58.

Chomsky, N. (1995). The minimalist program. Cambridge, MA: MIT Press.

Cohen, D. (1977). Psychologists on Psychology. NY: Taplinger.

Decety, J., \& Sommerville, J.A. (2003). Shared representations between self and other: A social cognitive neuroscience view. Trends in Cognitive Sciences, 7, 527-533.
Elman, J.L. (1993). Learning and development in neural networks: The importance of starting small. Cognition, 48, 71-99.

Elman, J.L., Bates, E., Johnson, M., Karmiloff-Smith, A., Parisi, D., \& Plunkett, K. (1996). Rethinking innateness: A connectionist perspective on development. Cambridge, MA: MIT Press.

Fraser, C., Bellugi, U., \& Brown, R. (1963). Control of grammar in imitation, comprehension, and production. Journal of Verbal Learning and Verbal Behavior, 2, 121-135.

Gallo, P. (1994a). ¿Se adquiere un lenguaje sin esfuerzo? Las dificultades que plantea una lengua pro-drop. In S. López Ornat, P. Gallo, A. Fernández, \& S. Mariscal, La adquisición de la lengua española (pp. 24-46). Madrid: Siglo XXI.

Gallo, P. (1994b). Adquisiciones en torno al imperativo: lo que se aprende dando órdenes. In S. López Ornat, P. Gallo, A. Fernández, \& S. Mariscal, La adquisición de la lengua española (pp. 47-58) . Madrid: Siglo XXI.

Halliday, M.A.K. (1973). Explorations in the function of language. London. Arnold.

Hauser, M.D., Chomsky, N., \& Fitch, W.T. (2002). The faculty of language: What is it, who has it, and how did it evolve? Science, 298, 1569-1579.

Jusczyk, P.W. (1997). The discovery of spoken language. Cambridge, MA: MIT Press.

Lecanuet, J.P., \& Granier-Deferre, C. (1993). Speech stimuli in the fetal environment. In de Boysson Bardies, S. de Schonen, P. 
Jusczyk, P. MacNeilage, \& J. Morton (Eds.), Developmental neurocognition: Speech and voice processing in the first year of life (pp. 237-248). Dordrecht: Kluwer.

Lieven, E., Behrens, H., Spears, J., \& Tomasello, M. (2003). Early syntactic creativity: A usage-based approach. Journal of Child Language, 30, 333-370.

Lieven, E., Pine, J.M., \& Baldwin, G. (1997). Lexically-based learning and early grammatical development. Journal of Child Language, 24, 1, 187-219.

López Ornat, S. (1991). El lenguaje en la mente. In J. Mayor \& J.L. Pinillos (Series Eds.) \& M.M. Serrano \& M. Siguán (Vol. Eds.), Tratado de psicología general: Vol. VI. Comunicación y Lenguaje (pp. 443-462). Madrid: Alhambra Universidad.

López Ornat, S. (1994). La adquisición gramatical: un esquema. In S. López Ornat, P. Gallo, A. Fernández, \& S. Mariscal, La adquisición de la lengua española (Chap. 8). Madrid: Siglo XXI.

López Ornat, S. (1996). Mecanismos de adquisición morfosintáctica. In M. Pérez-Pereira (Ed.), Estudios sobre la adquisición del castellano, catalán, eusquera y gallego (pp. 175-193). Santiago de Compostela: Publicaciones de la Universidad de Santiago de Compostela.

López Ornat, S. (1997). What lies in-between a pre-grammatical and a grammatical representation? In W.R. Glass \& A.T. PérezLeroux (Eds.), Contemporary perspectives on the acquisition of Spanish (pp. 3-20). Sommerville, MA: Cascadilla Press.

López Ornat, S. (1999). La adquisición del lenguaje: nuevas perspectivas. In M. de Vega \& F. Cuetos (Coords.), Psicolingüística del español (pp. 469-533). Madrid: Trotta.

López Ornat, S. (2001). Fillers: How much do they generalize? Journal of Child Language, 28, 266 -268.

López Ornat, S. (2003a). Learning earliest grammar: Evidence of grammar variations in speech before 22 months. In S. Montrul \& F. Ordóñez (Eds.), Linguistic theory and language development in Hispanic languages (pp. 254-274). Sommerville, MA: Cascadilla Press.

López Ornat, S. (2003b). Problemas ficticios y problemas reales sobre el desarrollo gramatical. Comentario. Cognitiva, 15, 177185.

López Ornat, S., Gallo, P., Fernández, A., \& Mariscal, S. (1994). La adquisición de la lengua española. Madrid. Siglo XXI.

MacWhinney, B. (2002). The gradual emergence of language. In T. Givón \& B. Malle (Eds.), The evolution of language (pp. 1-28). Philadelphia, Benjamins.

Maratsos, M. (1998). The acquisition of grammar. In W. Damon (Ed.), Handbook of child psychology: Vol. 2. Cognition, Perception and Language ( $5^{\text {th }}$ ed., pp. 421-466). NY: Wiley.

Marcus, G.F. (1999). Connectionism: With or without rules? Trends in Cognitive Science, 3, 168-170.

Mariscal, S. (1997). El proceso de gramaticalización de las categorías nominales en español. Doctoral dissertation. Microfile ISBN: 84-7477-740-2. Madrid: Autonomous University of Madrid.
Mariscal, S. (2001). ¿Es “a pé” equivalente a Det+N?: sobre el conocimiento temprano de las categorías gramaticales. Cognitiva, 13, 1, 35-59.

Mateo, M.A. (2000). El objeto de la psicología como sistema dinámico. Boletín de Psicología, 68, 7-30.

McClelland, J.L., \& Plaut, D.C. (1999). Does generalization in infant learning implicate abstract algebra-like rules? Trends in Cognitive Science, 3, 166-168.

Pérez-Pereira, M. (1994). Imitations, repetitions, routines and the child's analysis of language: Insights from the blind. Journal of Child Language, 21, 317-337.

Pérez-Pereira, M., \& Castro, J. (1994). El desarrollo psicológico de niños ciegos en la primera infancia. Barcelona, Paidos.

Piaget, J. (1981). El papel de la imitación en la formación de la representación. Monografías de Infancia y Aprendizaje, 2, 229235.

Pine, J. M. (1994). The language of primary caregivers. In C. Gallaway \& B. Richards (Eds.), Input and interaction in language acquisition (pp.15-37). Cambridge UK: Cambridge University Press.

Pine, J., \& Lieven, E. (1997). Slot and frame patterns in the development of the determiner category. Applied Psycholinguistics, 18, 123-138.

Pinker, S. (1987). The bootstrapping problem in language acquisition. In B. MacWhinney (Ed.), Mechanisms of language acquisition (pp. 399-441). Hillsdale, NJ: Erlbaum.

Plunkett, J. (1993). Making nets work hard. Mind \& Language, 8, 549-558.

Plunkett, J. (1995). Connectionist approaches to language acquisition. In P. Fletcher \& B. MacWhinney (Eds.), The handbook of child language (pp. 36-72). Oxford, UK: Blackwell

Quartz, S.R., \& Sejnowski, T.J. (1997). The neural basis of cognitive development: A constructivist manifesto. Behavioral \& Brain Sciences, 20, 537-596.

Rivière, A. (1991). Objetos con mente. Madrid: Alianza.

Seidenberg, M.S. (1997). Language acquisition and use: Learning and applying probabilistic constraints. Science, 275, 1592-1603.

Skinner, B.F. (1957). Verbal Behavior. NY: Appleton. [Spanish translation: Conducta Verbal. Mexico, Trillas (1957).].

Smith, P., Nix, A., Davey, N., López-Ornat, S., \& Messer, D. (2003). A connectionist account of Spanish determiner production. Journal Child Language, 30, 305-331.

Snow, K., \& Ferguson C. (1977). Talking to children: Language input and acquisition. Cambridge, MA: CUP.

Tomasello, M. (2000). Do young children have adult syntactic competence? Cognition, 74, 209-253.

Tomasello, M. (2003). Constructing a language: A usage-based theory of language acquisition. Cambridge \& London: Harvard University Press.

Received May 7, 2004

Revision received 16 August, 2004 Accepted September 1, 2004 